\title{
MOŽNOSTI IDENTIFIKÁCIE POMOCOU RFID TECHNOLÓGIE
}

\author{
Anna Pad'ourová ${ }^{1}$, Margita Majerčáková ${ }^{2}$
}

RFID (Radio Frequency Identification - rádio frekvenčná identifikácia) predstavuje najvýznamnejšiu technológiu posledného desat'ročia. Táto technológia využíva elektromagnetické signály na automatickú identifikáciu objektov vzdialených aj niekol'ko metrov, ktoré nemusíme priamo vidiet' a môžu sa aj pohybovat'.

\section{RFID identifikácia budúcnosti}

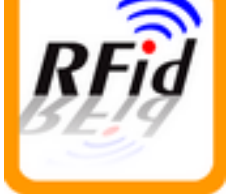

RFID patri medzi novú generáciu v oblasti AIDC (Automatic Identification Data Capture) technológií. Ponúkajú výhody, ktoré neposkytujú iné AIDC systémy (napríklad čiarový kód). RFID je systém pracujúci v pásme rádio frekvenčných vín. Je to vlastne bezdotyková automatická identifikácia, ktorá sa používa na prenos a ukladanie dát pomocou elektromagnetických vín. Činnost' systému je vel'mi jednoduchá. Základným princípom je uloženie potrebných dát v pamät'ových rádio - frekvenčných čipoch a následne opakované čítanie prípadne zápis dát pomocou čítačky. Č́tacie zariadenie má podobu pevnej brány, alebo ručného terminálu. Bezdrôtová komunikácia prebieha pomocou antény na príslušných rádio frekvenčných vlnách. Informácie získavané v priebehu výrobného alebo logistického procesu sú filtrované pomocou softvérového vybavenia - middleware (je to softvér, ktorý zabezpečuje spracovanie načítaných dát a prenos do informačného alebo riadiaceho systému) na využitie v informačnom systéme. Identifikácia produktov a ich ledovatel'nost' je uskutočňovaná celosvetovo. Blokovú schému systému RFID znázorňuje obr. č. 1

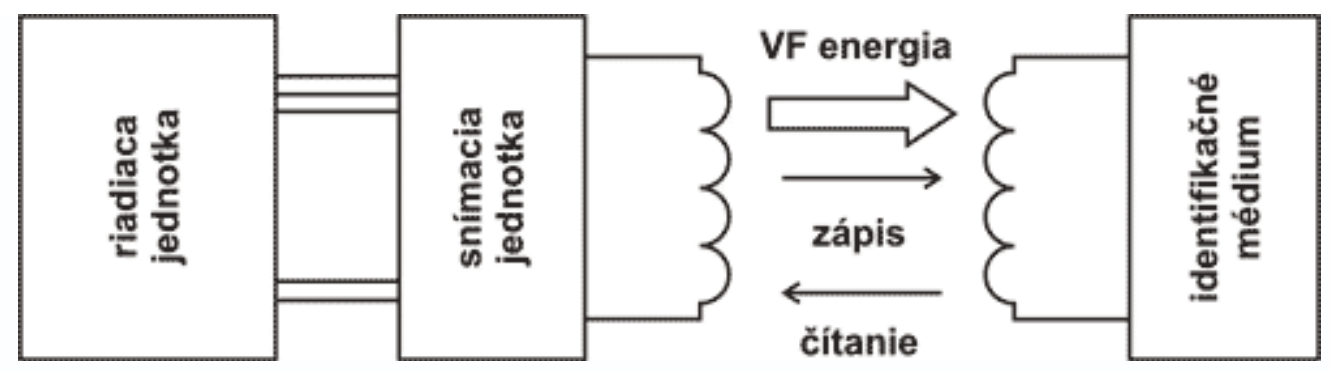

Obr. č. 1 Bloková schéma rádio frekvenčného systému

\footnotetext{
${ }^{1}$ Ing. Anna Pad’ourová, PhD., Žilinská univerzita v Žiline, Fakulta prevádzky a ekonomiky dopravy a spojov, Katedra spojov, Univerzitná 1, 01026 Žilina, tel.: 041/5133129, fax: 041/5655 615, e-mail: Anna.Padourova@fpedas.uniza.sk

${ }^{2}$ Dr. Ing. Margita Majerčáková, Katedra spojov, Fakulta prevádzky a ekonomiky dopravy a spojov, Žilinská univerzita v Žiline, Univerzitná 1, 01026 Žilina, Slovenská republika, tel.: +421415133126, fax: +421415655615 e-mail: Margita.Majercakova@fpedas.uniza.sk
} 
Dáta „do“ alebo , $\mathbf{Z}^{\text {“ }}$ identifikačného média sa prenášajú rádio frekvenčnými vlnami (RF). Väčšina RFID systémov umožňuje súčasný zber dát $\mathrm{z}$ viacerých identifikačných médií $\mathrm{v}$ dosahu snímacej jednotky. Identifikačné médiá RFID môžu byt' uzatvorené v odolnom obale, čo zvyšuje ich trvanlivost' a odolnost' pri nepriaznivých podmienkach.

\section{RFID čipy používané dnes}

Pôvodným zámerom bol vývoj RFID ako alternatívy v aplikáciách, kde bolo využitie čiarových kódov náročné alebo úplne nemožné. V súčasnosti už existuje široká paleta systémov RFID, ktoré sa klasifikujú na základe troch kritérií:

- nosič energie;

- oblast' frekvenčného vysielania;

- funkčná špecifikácia.

\section{podl'a zdroja napájania alebo nosiča energie}

- pasívne - najrozšírenejšie, nemajú vlastný zdroj energie, na prenos informácie je potrebná energia z cudzieho zdroja, t. j. z antény čítacieho zariadenia. Výhodou je nízka cena, neobmedzená životnost' a malá konštrukčná vel'kost'.

- aktívne - majú zabudovaný vlastný zdroj energie. Sú využívané v systémoch, ktoré potrebujú dlhšiu prenosovú vzdialenost'. Sú schopné realizovat' zber, vyhodnocovanie a spätné odosielanie údajov. Nevýhodou sú vel'ké rozmery a obmedzená životnost', ktorá závisí od kvality batérie.

\section{podl'a frekvenčného pásma}

Systémy RFID pracujú s rôznymi frekvenciami, ich výber vychádza $\mathrm{z}$ analýzy riešenia. Najskôr sa musia určit' požiadavky na rýchlost' čítania a zápisu, dosah signálu a priestor pokrytia atd'. Prehl'ad je uvedený v nasledovnej tabul'ke č. 1

Tab. č. 1 Frekvencie systémov RFID

\begin{tabular}{|c|c|c|}
\hline Frekvencia & Dosah & Popis \\
\hline $\begin{array}{l}125-134 \mathrm{kHz}(\mathrm{LF}) \\
\text { nízka frekvencia }\end{array}$ & $\max .0,5 \mathrm{~m}$ & 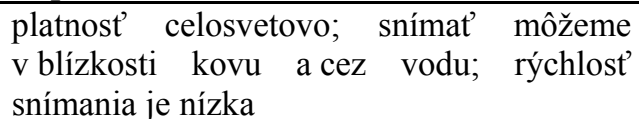 \\
\hline $\begin{array}{l}13,56 \mathrm{MHz}(\mathrm{HF}) \\
\text { vysoká frekvencia }\end{array}$ & $\max .1 \mathrm{~m}$ & $\begin{array}{l}\text { platnost' celosvetovo; komplikované } \\
\text { snímanie cez vodu; rýchlost' snímania / } \\
\text { zápis cca. 10x rýchlejší ako LF }(20 \mathrm{kB} / \mathrm{s})\end{array}$ \\
\hline $\begin{array}{l}865-869 \mathrm{MHz} \text { (UHF) } \\
\text { vel'mi vysoká frekvencie }\end{array}$ & $\max .3 \mathrm{~m}$ & $\begin{array}{l}\text { UHF platné pre Európu; nie je možné } \\
\text { snímat' cez kvapalinu a vel'mi } \\
\text { komplikované snímanie cez kov }\end{array}$ \\
\hline $\begin{array}{l}902-928 \mathrm{MHz}(\mathrm{UHF}) \\
\text { vel'mi vysoká frekvencia }\end{array}$ & $\max .3 \mathrm{~m}$ & UHF platné pre USA, Kanadu a Mexiko \\
\hline $\begin{array}{l}950-956 \mathrm{MHz}(\mathrm{UHF}) \\
\text { vel'mi vysoká frekvencia }\end{array}$ & $\max .3 \mathrm{~m}$ & UHF platné pre Áziu a Japonsko \\
\hline $\begin{array}{l}2,45 \mathrm{GHz} ; 5,8 \mathrm{GHz}(\mathrm{MW}) \\
\text { mikrovlnná frekvencia }\end{array}$ & $\max .10 \mathrm{~m}$ & $\begin{array}{l}\text { možnost' čítania pri vel'mi vysokých } \\
\text { rýchlostiach; vysoká cena čipov }\end{array}$ \\
\hline
\end{tabular}

\section{podl'a prevedenia}

RFID tag - pamätový rádio frekvenčný čip, ktorý je nosičom dátovej informácie. Skladá sa z vlastného čipu, antény a prepojenia. Čip určuje kapacitu a typ RFID tagu, anténa stanovuje kvalitu príjmu a odosielania RF signálu.

RFID smart label - RFID čip, ktorý je umiestnený na potlačenej etikete s možnost'ou d'alších informácií (textu, grafiky). 
RFID wristband - náramok na ruku, ktorý obsahuje RFID čip využívaný v zdravotníctve na identifikáciu osôb.

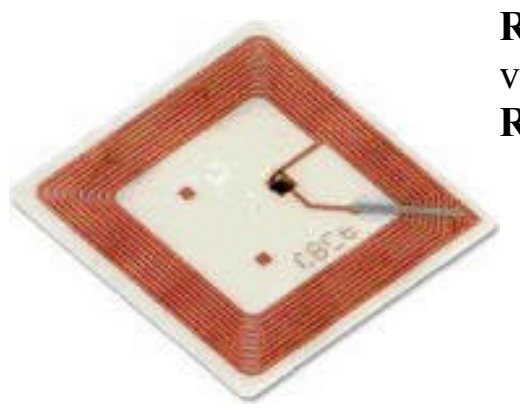

RFID karta - čip, ktorý môže byt' v plastovej karte, alebo v kl'účenke

RFID inlay - čip je zabudovaný priamo do produktu

\section{podl'a možnosti zápisu}

- Ien na čítanie (Class 0), majú dosah 3 až 10 metrov, kapacitu pamäte 64 - 96 bitov, cena je najnižšia, čítanie 1000 tagov/s;

-zapisovatel'né 1x alebo viacnásobne (Class 1), majú vyššiu pamät' a zaručujú aj väčšiu bezpečnost', čítanie 200 tagov/s;

-zapisovatel'né viacnásobne (Class 0+), 256bit, čítanie1000 tagov/s

-zapisovatel’né viacnásobne (Gen2), 256bit, čítanie1600 tagov/s

\section{Technologické a ekonomické výhody RFID oproti čiarovým kódom}

- bezkontaktní prenos dát, to znamená, že nie je nutná priama viditel'nost' čipu;

- vyššia rýchlost' prenosu dát a minimalizácia chybovosti čítania dát;

- vyššia odolnost' nositel'a dát proti vlhkosti, teplote, prašnosti, vibráciám a pod.;

- dáta zapísané v RFID tagu je možné neskôr aktualizovat', alebo dopínat';

- možnosti čítacieho zariadenia snímat' súčasne vel'ké množstvo tagov;

-identifikácia pomocou nezamenitel'ného sériového čísla výrobku;

- vyššia rýchlost' uskutočňovaných operácií (skladových, inventarizácia majetku atd’.);

- minimalizácia l'udského faktoru a chybovosti;

- zjednodušenie výmeny dát a identifikácie;

- návratnost' počiatočných investícii zaručená využívaním efektívnej technológie.

$\mathrm{Na}$ zabezpečenie základných identifikácii s nižšími nákladmi sú vhodnejšie čiarové kódy.

- čiarový kód využíva na kódovanie farebný kontrast medzi čiarkami a medzerami;

- snímanie čiarových kódov trvá niekedy aj niekol'ko minút;

- obsahuje iba informáciu o druhu výrobku;

-je potrebná priama viditel'nost' medzi čiarovým kódom a snímacím zariadením;

- pravdepodobnost' poškodenia čiarového kódu pri manipulácii je vyššia.

V tabul'ke č. 2 je uvedené prehl'adne porovnanie RFID a čiarového kódu EAN

Tab. č. 2 Porovnanie RFID a čiarového kódu EAN

\begin{tabular}{|l|l|l|}
\hline & RFID & ČIAROVÝ KÓD EAN \\
\hline Objem informácií & vysoký & nízky \\
\hline Č́ítanie viacero údajov/identifikácií naraz & áno & nie \\
\hline Integrácia do systému & náročná & jednoduchá \\
\hline Úroveň sledovania & vysoká & stredná \\
\hline
\end{tabular}




\begin{tabular}{|l|l|l|}
\hline Štruktúrovanie dát & vysoké & nízke \\
\hline Úspora času a námahy práce & vysoká & stredná \\
\hline Životnost' & dlhá & krátka \\
\hline Odolnost' & vysoká & nízka \\
\hline Aktualizácia uloženej informácie & áno & nie \\
\hline Automatizácia prevádzky/výroby & áno & áno, s obmedzeniami \\
\hline Počiatočné investície & vysoké & nízke \\
\hline Súčasný rozsah používania & novinka - nízky, & vysoký \\
\hline Štandardy & áno, vo vývoji & áno \\
\hline
\end{tabular}

\section{Čo s čiarovými kódmi?}

S nástupom tejto technológie sa čiarové kódy nestanú technológiou zastaranou alebo nepoužitel'nou. Čiarové kódy aj nad'alej zostanú v mnohých aplikáciách vhodnejším riešením. V praxi v mnohých prípadoch sa môže využit kombinácia čiarových kódov a RFID , čo znamená že táto technológia v žiadnom prípade nenahradí čiarové kódy. RFID nájde svoje uplatnenie $\mathrm{v}$ aplikáciách so špecifickými požiadavkami, alebo pri riešeniach vyžadujúcich prednosti tejto technológie.

\section{Uplatnenie RFID technológie v praxi}

Možnosti nasadenia RFID technológie v praxi sú vel'mi široké a nie sú už len otázkou budúcnosti. V súčasnosti sa najviac používa v obchodnom sektore, kde slúži na ochranu obchodníkov pred krádežami. K d’alším odvetviam využitia uvedenej technológie patri aj:

\section{Logistika - sledovanie prepravných jednotiek}

- sledovanie logistických jednotiek (napr. palety, kontajnery) s možnost’ou rýchleho načítavania niekol'kých jednotiek súčasne;

- sledovanie umiestnenia jednotky globálne - zmena trasy, ich lokalizácia a pod.;

- vel'koobchod, supermarkety - „načítavanie“ nákupu zákazníka vo vozíku, sledovanie pohybu cenného tovaru.

Výroba - traceabilita (sledovanie výroby)

- presná identifikácia produktov v priebehu ich výrobného procesu;

- automatické riedenie a zmeny vo výrobnom postupe;

- spätná vysledovatel'nost' „histórie“ produktu.

Pošta - automatické spracovanie a kontrola zásielok

- jeden z najväčších projektov RFID v Európe (2300 antén, 330 čítačiek, 13 tisíc pasívnych RFID etikiet)

- automatické sledovanie zásielok, kontrola zistenej lokalizácie, okamžitá korekcia nesprávnej prepravy zásielky.

\section{Záver}

Rozsah využívania RFID technológie v bežnom živote súvisí s mnohými otázkami. Jednou $\mathrm{z}$ hlavných a najdiskutovanejších je určenie hranice, kedy RFID technológia začína zasahovat' do súkromia, d’alšie sa dotýkajú oblasti bezpečnosti a zneužitia RFID technológie. Aj napriek týmto otázkam môžeme surčitost'ou povedat', že RFID technológiu čaká rozžiarená budúcnost'. 


\section{Literatúra}

[1] VACULÍK J.: Nové prvky v poštovej logistike In: Logistika : měsíčník Hospodářských novin. - ISSN 1211-0957. - Roč. 14, č. 3 (2008), [2 s.].

[2] KOLAROVSZKI P., VACULÍK J.: Balíkové zásielky v spojení s technológiou RFID In: Diagnostika podniku, controlling a logistika [elektronický zdroj] : IV. medzinárodná vedecká konferencia : zborník príspevkov : 17.-18. apríl 2008, Žilina. - Žilina: Žilinská univerzita, 2008. - ISBN 978-80-8070-819-1. - S. 117-122. - Požiadavky na systém: CD ROM mechanika.

[3] KOLAROVSZKI P., VACULÍK J.: RFID pomôže, len ak s ním viete pracovat' : Rádiofrekvenčná identifikácia nesie pre firmy vážne riziká / . In: Doprava a logistika : odborný mesačník vydavatel'stva Ecopress. - ISSN 1337-0138. Roč. 3, č. 1 (2008), s. 20-21.

[4] KMENT, M., SVATOŠ, D.: Základy technológie RFID a možnosti jejího využití. AT\&P journal 9/2002, s. $77-79$

[5] DOLNÁK I., VACULÍK J.: RFID attacks and information security [Útoky na RFID a informačná bezpečnost'] / . In: The Internet, Competitiveness and the Organisational Security [elektronický zdroj] : X Annual International Conference : Zlín, 26th March 2008 : conference proceedings. - Zlín: Tomas Bata University, 2008. - ISBN 978-807318-548-0. - [4 s.]. - Požiadavky na systém: CD-ROM mechanika. Vyšiel aj tlačený zborník anotácií ; s. 21

\section{Grantová podpora}

AV: 4/2045/08 Aplikácia technológie RFID pre vybrané poštové procesy na podmienky HSS

MVTS: ČR/SRŽU4/08 Možnosti využitia technológie rádio frekvenčnej identifikácie v prepravných procesoch poštových operátorov 